UDC 341.637

DOI: $10.5937 / R K S P P 2001047 \mathrm{~L}$

MILAN LAZIĆ

GIULIO PALERMO

SRDAN DRAGIĆEVIĆ

\title{
EX AEQUO ET BONO IN INTERNATIONAL ARBITRATION
}

The notion of ex aequo et bono is rarely entertained in international arbitration. In its basic form, it entails the application of the arbitrator's own sense of justice and good as the law governing the underlying contract or transaction, as opposed to the strict letter of an otherwise applicable set of norms anchored in a specific legal order. The notion essentially embodies the foundation and purpose of any dispute resolution mechanism, which is to provide just and equitable legal protection to interested/disputing parties, avoiding the sometimes overly strict or rudimentary statutory rules. Yet, ex aequo et bono is often challenged for the supposed dangers of uncertainty, unpredictability and subjectivism it poses, as well as the possibility of inducing arbitrariness or even abuse of powers. In this article, we seek to demonstrate that the application of ex aequo et bono is not only reasonable in certain cases and industries, but also very effective in terms of duration and costs of arbitral procedure, while preserving legal certainty and the application of the basic legal principles. Moreover, we seek to demonstrate that awards rendered ex aequo et bono are as enforceable as any other arbitral award and not riskier with respect to alleged arbitrariness or excessive discretion.

Key words: arbitration, applicable law, legal certainty, equity, public policy

Milan Lazić, Senior Partner, Karanović \& Partners law office, Belgrade, attorney at law, e-mail:milan.lazic@karanovicpartners.com

Giulio Palermo, Partner, Archipel law office, Geneva, attorney at law, e-mail: gpalermo@archipel.law

Srđan Dragićević, Associate, Karanović \& Partners law office, Belgrade, e-mail: srdjan.dragicevic@ karanovicpartners.com 


\section{INTRODUCTION}

Upon offering a definition of ex aequo et bono, we attempt to clear the scenery from the prejudices and confusion that are often associated with the same. Thereafter, we analyze how arbitrators apply and decide dispute ex aequo et bono in practice through an illustration of both selected case law and legislation. We then assess the pros and cons of ex aequo at bono vis-à-vis ex lege arbitration. While noting the concerns for its application, we conclude that a more frequent reliance on ex aequo et bono could lead to a more efficient and user-friendly adjudication of cross-border disputes in certain cases.

\section{WHAT IT IS AND WHAT IT IS NOT \\ - TACKLING COMMON MISCONCEPTIONS}

\section{Definition}

The power to decide ex aequo et bono normally refers to the substance of a dispute and it does not concern the conduct of the arbitral proceedings; ${ }^{1}$ the latter are governed by the lex arbitri, in ex lege and ex aequo et bono arbitrations alike.

The first fundamental conceptual distinction to be made is that a decision ex aequo et bono is based on considerations of what is equitable and good, while a decision ex lege is based on one or more specific law/s. Thus, in principle, an arbitral award decided ex aequo et bono consists in a decision of what is just and fair based on an individual/concrete, case-specific rule, without consideration of abstract legal provisions. ${ }^{2}$

The precise considerations on the basis of which arbitrators may reach a decision as to what is just and fair are addressed further below. At the present stage, it is important to first clear the scenery from a number of common misconceptions about the topic under examination.

\section{Differences}

Although ex aequo et bono and equity seems to have the same legal meaning, they may have slightly different implications. Equity usually operates as an additional and/or residual tool to decide a certain dispute while "a decision ex

1 Tobias Zuberbühler, Klaus Muller, et al., Swiss Rules of International Arbitration: Commentary, Kluwer Law International, 2005, 299.

2 Gabrielle Kaufmann-Kohler, Antonio Rigozzi, Arbitrage international: droit et pratique à la lumière de la LDIP, 2nd ed. Bern: Weblaw, 2010, para. 7.67. 
aequo et bono shall not be made according to ius in any respect but based on equitas". ${ }^{3}$

This distinction is helpful in addressing yet another misconception, namely the often interchangeable use of the terms ex aequo et bono and amiable compositeur. To clarify, arbitrators deciding as amiable compositeur must apply the lex causae, but are then entitled to mitigate its effects if they consider its application unfair. ${ }^{4}$ The power to act as amiable compositeur is therefore "a dispensation, foreseen by the law itself, from strictly applying the rules of law".

Conversely, arbitrators deciding ex aequo et bono: (i) must exclusively focus on the factual circumstances of the case; (ii) may, but are neither requested nor bound to, consider any specific rules of law; (iii) modify the terms of the parties' agreements.

Lastly, it is noteworthy that scholars and case $\operatorname{law}^{6}$ agree that arbitrators are not prevented from ruling ex aequo et bono by applying the legal rules (including general principles of $l a w^{7}$ ) that they deem relevant to the case at hand. ${ }^{8}$ As illustrated in the following sections of the present article, case law indeed shows that arbitrators have generally applied ex aequo et bono in a way that mirrors "generally accepted principle[s] which [are] embodied in most legal systems". 9

\section{Myth and Reality}

Many authors identify uncertainty, unpredictability, excessive discretion or potential abuse of powers by arbitrators as main the concerns surrounding the conferral of ex aequo et bono authority to the arbitral tribunals. ${ }^{10}$

3 Bernhard Berger, Franz Kellerhals, International and Domestic Arbitration in Switzerland, Bern, 2015, para. 1439.

4 B. Berger, F. Kellerhals, op. cit., para. 1448.

5 R.H. Christie, "Amiable composition in French and English law" Arbitration, Vol. 58, No. 4, 1992, footnote $28,259$.

6 FSCD 110 Ia 56 [58], VD 19.05.1999, 13: "If an arbitrator is mandated to decide as an amiable compositor and therefore decides, with the exception of the public policy provisions, ex aequo et bono, this does not prevent it from deciding on the basis of a certain law, if it considers that this is in conformity with an ex aequo et bono decision".

7 Erika Hasler, "The Basketball Arbitral Tribunal - An Overview of Its Process and Decisions", Yearbook of International Sports Arbitration 2015, The Hague, 2016, 133.

8 G. Kaufmann-Kohler, A. Rigozzi, op. cit., para. 7.71.

9 BAT 0392/13, para. 76 (available at: https://bit.ly/2IJz8Sv, 10.04.2020.); see also BAT 0480/13, para. 88 (available at: https://bit.ly/2IL6znW, 10.04.2020.).

10 Nobumichi Teramura, “The Strengths and Weaknesses of Arguments Pertaining to Ex Aequo Et Bono", Asian International Arbitration Journal, Kluwer Law International, Vol. 15, 2019, 74-78. 
Risks related to the interpretation of facts and law. - The first group of reasons for concern depart from the premise that the laws and regulations provide for certainty and predictability in arbitration proceedings while ex aequo et bono does not. Whereas the letter of the law does bring certainty and (to a certain extent) clarity, its application to determined facts by different arbitrators certainly do not necessarily do so. The uncertainty may already begin at the phase of determination of facts (i.e. taking of evidence to determine disputable facts) which, except for public policy issues, is an exercise that falls outside of the scope of review of national courts in many jurisdictions. ${ }^{11}$

Moreover, although in certain jurisdictions failing to apply the chosen law constitutes grounds for setting aside, ${ }^{12}$ it does not mean that an incorrect application of the chosen law might equally lead to setting aside/non-enforcement. ${ }^{13}$

Thus, depending on the applicable lex arbitri, the level of uncertainty and unpredictability in relation to arbitrators' interpretations of the facts and of the law is potentially the same in ex aequo et bono arbitrations as in other arbitrations.

Risks related to subjectivism and arbitrariness. - The second group of reasons for concern is a consequence of the view that taking ex aequo et bono approach necessarily entails a subjective approach of an arbitrator - it is an internal sense of what is just and correct and what is not. However, this is something that, by definition, cannot (and should not) be excluded in any arbitral proceedings the thinking process of an arbitrator when adjudicating a case is necessarily an internal, subjective process of what an arbitrator thinks is the universally and objectively fair and correct result in a particular situation. As such, the argument that ex aequo et bono is more prone to excessive discretion than in other arbitrations does not stand.

11 Ex multis, in Switzerland 4A_474/2013 para. 5.1, or 4A_256/2013 para. 2.2. Interestingly, Switzerland is among the few jurisdictions in which also invoking public policy, whether substantive or procedural, cannot lead to a review by the Federal Tribunal of the manner in which the facts were found or the evidence assessed by the arbitrators, ex multis 4A_530/2013 para. 6.1.

12 In Switzerland the court of annulment "will not review, under the guise of an alleged violation of public policy, whether the determination of the applicable law was correct or whether the applicable law was correctly applied" FSCD 4A_624/2009 c. 3.2.2, FSCD 4A_260/2009 c. 3.2.2. This is also the case when "[a] decision rendered in equity, instead of according to the rules of law chosen by the parties [which] does not violate public policy if the application of the chosen rule of law would not have led to a fundamentally different result, which would also have been compatible with public policy" FSCD 116 II 634 [637].

13 Ibidem. 
Taking the assessment of a witness evidence as an example, it all comes down to whether an arbitrator believes a certain witness or not (in addition to comparing the statement to other witness statements and putting it into context vis-à-vis other evidence). It is therefore unclear why the same level of discretion should be considered unacceptable when it comes to applying ex aequo et bono principles on determined facts.

Depending on the applicable lex arbitri, ex aequo et bono arbitrators are, much like ex lege arbitrators, obliged to provide reasons for their decision; this limits the maneuver space for abuse of powers and excessive discretion. As in ex lege proceedings, a potential abuse of powers or excessive discretion by an ex aequo et bono arbitrators also limited by: (i) issues of public policy and (ii) the scrutiny of both the co-arbitrators and arbitral institutions.

Lastly, certain jurisdictions consider that arbitrariness of both ex aequo et bono and ex lege awards (i.e. conclusions which are evidently wrong and contrary to the content of the file) are not per se sufficient to set aside the arbitral award. ${ }^{14}$

In light of the above, depending on the applicable lex arbitri, the factors that truly prevent arbitrators from acting arbitrarily or in breach of their powers is the same in both ex lege and ex aequo et bono proceedings.

It can therefore be claimed that unpredictability and arbitrariness are the result of a wrong choice of a certain individual as arbitrator, rather than of a given authority to decide a case ex lege or ex aequo et bono.

Risks related to the rule making process. - The third group of reasons for concernis related to the fact that ex aequo et bono can be considered "more rule making than dispute settlement. ${ }^{15}$ This is based on the assumption that when arbitrators are empowered to decide ex aequo et bono, they can potentially add to or diminish the rights of the parties; this would be at odds with the very function of dispute resolution, which is a "backwards orientated task" 16 meant to focus on the determination of pre-existing rights.

In light of the above-described arbitrators' subjectivism and broad interpretations of the facts and of the law, it is unclear why the same criticisms would not extend to arbitration proceedings decided ex lege. Moreover, as explained in the following sections, the corrective equity approach to ex aequo et bono diminishes the relevance of such a concern.

14 4P.134/2006, cons. 3, 7.

15 Stefan M. Kroll, "Contractual Gap-Filling by Arbitration Tribunals”, International Arbitration Law Review, Vol. 2, 1999, 12.

16 Ibidem. 
Lastly, case law indicates that ex aequo et bono's possible rule-making function could, on the one hand, be seen as an additional element to reduce and control the above-described arbitrators' subjectivism and, on the other hand, be considered as an opportunity to promote the use of arbitration in certain industries.

\section{WHEN IS EX AEQUO ET BONO APPLIED AND HOW}

Ex aequo et bono applies to the merits of the dispute instead of national or international legislation, only when no choice-of-law clause has been agreed between the parties and provided that the parties have explicitly agreed ( $a b$ initio or once the dispute has arisen) that the arbitral tribunal can adjudicate ex aequo et bono.

The UNCITRAL Model law on International Commercial Arbitration recognizes that the parties may authorize the arbitral tribunal to decide the dispute $e x$ aequo et bono or as amiable compositeur. ${ }^{17}$ In Serbia, the relevant source of law for the application of ex aequo et bono is the Serbian Law on Arbitration, providing that the arbitral tribunal may decide on the basis of justice and equity (ex aequo et bono, amiable composition) only if the parties have expressly agreed so. ${ }^{18}$ Similar provisions are contained in the rules of arbitral institutions in Serbia. ${ }^{19}$ As such, in line with the UNCITRAL Model law, the condition under Serbian law is that the parties have expressly agreed that the arbitral tribunal may decide the case $e x$ aequo et bono.

Parties rarely authorize arbitral tribunals to decide ex aequo et bono. The ICC has noted approximately three arbitrations per year between 2003 and 2008 where such an authority was conferred on arbitral tribunals in ICC arbitrations. ${ }^{20}$ Gary Born notes that ex aequo et bono has been applied in at most 2-3\% of cases per year in commercial arbitrations. ${ }^{21}$

17 UNCITRAL Model Law on International Commercial Arbitration (1985, with amendments as adopted in 2006), Art. 28, Para. 3.

18 Law on Arbitration, Official Gazette RS, No. 46/2006, Article 49, Para. 2

19 Rules of the Permanent Arbitration at the Chamber of Commerce and Industry of Serbia, Official Gazette RS, No. 101/2016, Article 42, Para. 4; Rules of the Belgrade Arbitration Centre, Article 34, Para. 4.

20 Simon Greenberg, Christopher Kee, J. Romesh Weeramantry, International Commercial Arbitration: An Asia-Pacific Perspective, New York, Cambridge University Press, 2011, 143; Jeffrey Maurice Waincymer, Procedure and Evidence in International Arbitration, Kluwer Law International, 2012, 1046.

21 Gary B. Born, International Commercial Arbitration, Kluwer Law International, 2014, 2770. 
Sports arbitration likely represents the sector in which ex aequo et bono has found its broader application. The first ever decision of the Swiss-based Court of Arbitration for Sport ("CAS") was rendered ex aequo et bono. ${ }^{22}$ Despite this promising start, the vast majority of CAS' cases are decided ex lege. However, since 2007, another sport arbitral institution - i.e. the Basketball Arbitral Tribunal ("BAT") has adjudicated approximately 1500 ex aequo et bono ${ }^{23,24}$ owing to the fact that its arbitration rules provide that the default "Law Applicable to the Merits" is ex aequo et bono. As such, the present article refers extensively to BAT's case law in order to illustrate how ex aequo et bono has been applied in practice by arbitrators.

Apart from sports arbitration, other suitable fields for the application of ex aequo et bono principle may include: relationships which are not regulated by predetermined laws (e.g. unnamed contracts, such as different types of joint ventures); certain specialized disputes in different fields (e.g. IT, pharmaceutical, technology, etc.) in which the specialized knowledge and industry experience plays a vital role; certain areas of law (intellectual property, internet, media, maritime); state-investor disputes (when this is provided in the bilateral investment treaties or subsequently agreed between the parties).

An emblematic (but probably involuntary) description of the ex aequo et bono decision making process was provided right before his retirement by Judge Richard A. Posner, one of the most provocative figures in American law in the last half-century: "I pay very little attention to legal rules, statutes, constitutional provisions. A case is just a dispute. The first thing you do is ask yourself - forget about the law - what is a sensible resolution of this dispute?"25

\section{How to assess what is just and fair}

A useful way of understanding how arbitrators can in practice assess what is just and fair is to analyze the powers of arbitral tribunals to amend and alter par-

22 Erika Hasler, "Back to the Future: The First CAS Arbitrators on CAS's First Award (TAS 86/1, HC X c. LSHG) and Its Evolution Since Then", Yearbook of International Sports Arbitration 2016, The Hague, 2018, 6 .

${ }^{23}$ Basketball Arbitral Tribunal, available at: http://martens-lawyers.com/en/basketball-arbitral-tribunal-en/, 10.04.2020.

24 Basketball Arbitral Tribunal, available at: http://martens-lawyers.com/en/basketball-arbitral-tribunal-en/, 10.04.2020.

25 An Exit Interview With Richard Posner, Judicial Provocateur, available at: www.nytimes. com/2017/09/11/us/politics/judge-richard-posner-retirement.html, 10.04.2020. 
ties' agreements from the perspective of, and in accordance with the standards set by, BAT case law.

Contractual wording and the circumstances of the case. - BAT's case law shows that "the proper interpretation of an agreement is of foremost importance... ". ${ }^{26}$ The parties' contractual relationship ${ }^{27}$ is always the starting point of each ruling ex aequo et bono, i.e. "[t]he doctrine of pacta sunt servanda (which is consistent with justice and equity - parties who make a bargain are expected to stick to that bargain) is the principle by which the [a] rbitrator will examine the merits of the claims". ${ }^{28}$ The arbitrators "[i] nstead of applying general and abstract rules he/she must stick to the circumstances of the case". ${ }^{29}$

This is in line with Article 28(4) UNCITRAL Model Law, as well as various arbitration acts and rules, ${ }^{30}$ which states that arbitrators shall decide the case in accordance with the terms of the contract; and (ii) specify that arbitrators shall take into account the trade usages applicable to the transaction. ${ }^{31}$

By way of example, a decade of BAT case law $^{32}$ developed a robust set of interpretative principles which can be summarized as follows: (i) the meaning of the contractual language should be interpreted through the eyes of a reasonable reader; (ii) the clearer is the wording the more difficult it is to justify departing from it (i.e. in claris non fit interpretatio); (iii) the meaning could be further interpreted taking into account the overall factual background and general common understanding of the specific industry; (iv) nomen iuris is not binding for inter-

26 BAT 0756/15, [58] (available at: https://bit.ly/2UoCZMd, 10.04.2020.).

27 B. Berger, F. Kellerhals, op. cit., para. 1452.

28 BAT 0650/15, [33].

29 Concordat international sur l'arbitrage, Article 31, Para. 3.

${ }^{30}$ Ex multis, International Chamber of Commerce Arbitration Rules, Article 21, Para. 2; UNCITRAL Arbitration Rules (with new article 1, paragraph 4, as adopted in 2013), Article 35, Para. 3; Rules of the Permanent Arbitration at the Chamber of Commerce and Industry of Serbia, Official Gazette RS, No. 101/2016, Article 42, Para. 3; Swiss Rules of International Arbitration, Article 33, Para. 3.

31 Ex multis, International Chamber of Commerce Arbitration Rules, Article 21, Para. 2; UNCITRAL Arbitration Rules (with new article 1, para. 4, as adopted in 2013), Article 35, Para. 3; Rules of the Permanent Arbitration at the Chamber of Commerce and Industry of Serbia, Official Gazette RS, No. 101/2016, Article 42, Para. 3; Swiss Rules of International Arbitration, Article 33, Para. 3.

32 Ex multis, BAT 0756/15, para. 59 (available at: https://bit.ly/2UoCZMd, 10.04.2020.); BAT 0824/16, para. 49 to 52 (available at: https://bit.ly/2Ja0y37, 10.04.2020.); BAT 0845/16, para. 37 and 38 (available at: https://bit.ly/2X3SNFv, 10.04.2020); BAT 1019/17, para. 36 (available at: https://bit. ly/2xcmyEP, 10.04.2020.). 
pretation purposes; (v) the role of interpretation is not to assist an unwise party or to penalise an astute party.

Corrective equity. - Are arbitrators entitled to amend and/or disregard the parties' agreements? In principle, BAT jurisprudence observes that "it is not an arbitrator's mandate to replace the parties' express contractual arrangements by his or her own considerations of fairness and justice...the Arbitrator's power to adjust, or even mutual consensus should be used with extreme caution". 33

The above does not however mean that the arbitrators are not entitled to consider other elements, or even disregard the parties' contractual relationship. BAT case law indeed specifies that (i) arbitrators can indeed rely on "considerations of justice and fairness which may not be imminently rooted in the contractual language";34 (ii) "[o]ther facts may also be taken into consideration, especially if the wording is unclear or if a literal interpretation leads to a manifestly unfair and unjust result under the specific circumstances. Only in such cases, the Arbitrator is entitled under the concept of ex aequo et bono to deviate from the wording of the contract". 35

The following decision further provides an effective summary of the application of role of corrective equity in BAT's proceedings"[w] hile the principle pacta sunt servanda must be respected, the wording of the contract is an important but not the only element which must be examined and weighed to determine what the true intention of the parties was when they signed the agreement. There are indeed exceptions to the rule that the clear wording of a contractual provision must be followed, e.g. if the provision violates public policy principles or if it becomes obvious that the provision does not reflect the true intention of the parties (e.g. in case of fundamental error of a party) or if one party exploited the inexperience of the other party which resulted in a clear discrepancy between performance and consideration". ${ }^{36}$

As a consequence, considerations of equity may proportionally come into play only when the strict application of the contractual wording and the circumstances of the case would produce inequitable results. ${ }^{37}$

33 BAT 1124/17, para. 48 (available at: https://bit.ly/2WVqmoE, 10.04.2020.).

34 BAT 1158/18, [29], available at: www.fiba.basketball/en/Module/85132837-66aa-4ff3-a0638cdfe44ea14d/50a89343-d03a-4a12-8367-0d7df0d5ebf4, 10.04.2020.

35 BAT 0634/14, para. 70.

36 BAT 0634/14, paras. 69-70, available at: http://www.fiba.basketball/bat/awards, 10.04.2020.

37 Yoshifumi Tanaka, "Reflections on maritime delimitation in the Cameroon/Nigeria case", International \& Comparative Law Quarterly, Vol. 53, 2004, 392. 
Adaptation and integration of the contractual wording. - There are different opinions in theory and practice about whether an ex aequo et bono arbitral tribunal can go so far as to alter the terms of the contract that it deems unjust. Jarvin suggests that the terms of the contract may not be modified by an arbitrator acting as amiable compositeur. ${ }^{38}$ The Paris Court of Appeal has on a number of occasions concluded that the power to act as amiable compositeur does not allow arbitrators to 'modify the economics of the agreement. ${ }^{39}$ Swiss scholars and case law ${ }^{40}$ consider that arbitrators deciding ex aequo et bono are authorized to depart from the contract when the latter's application would result in an unfair, unjust or inequitable outcome. ${ }^{41}$

The middle view holds more validity; indeed, arbitrators should certainly not deviate from the genuine intent of the contract or change the very essence and structure of the agreement, but if a certain provision is obviously unfair or excessive or against the true intent of the parties or public policy, the arbitral tribunal should be allowed to alter the contract or bring it to its intended balance. ${ }^{42}$

Our understanding is substantiated by the following list of awards related to the closing of contractual gaps, mitigating the strictness of contractual provisions, adaptation of contracts, etc.

(i) Force majeure and hardship:

Certain legal systems provide that parties are entitled to invoke force majeure (i.e. permanent invincible obstruction to perform because of extraordinary events or circumstances that could not have been foreseen by the parties) or hardship (i.e. unforeseen events which significantly affected the initial equilibrium of the contract, by placing an excessive burden on one of the parties) only if they have contractually established this possibility and identified the events or circumstances that would trigger the application of such legal remedies. Under other le-

38 ICC Case No. 3938, 111 Clunet 926 (1984); J. Waincymer, op. cit., 1052.

39 J. Waincymer, op. cit., 1052; 6 May 1988, Revue de l’arbitrage, 1989, 63; 19 April 1991, Revue de l'arbitrage, 1991, 673 (annot. E Loquin) cited in Laurence Kiffer, "Amiable Composition in ICC Arbitration", ICC International Court of Arbitration Bulletin 18, No. 1, 2007, footnote 29.

40 FSCD 19.02.1990, ASA, 1991, 178-179: "An arbitral tribunal which decides as amicables compositeurs, and thereby departs from a contractual clause, does not violate public policy if it had been authorised not to take into account this provision, and this even in the absence of the powers of an amiable compositeur".

41 B. Berger, F. Kellerhals, op. cit., para. 1444; G. Kaufmann-Kohler, A. Rigozzi, op. cit., para. 7.72.

42 ICC Case No. 3267 Yearbook of Commercial Arbitration, Vol. VII (1982) 96; ICC Case No. 7913 cited in L. Kiffer, op. cit., 58; Paris 6 March 1988 Revue de l'arbitrage, 1989, 83 cited in L. Kiffer, op. cit., footnote 33 . 
gal systems these remedies can be invoked on the basis of limited statutory principles.

National laws do not however have clear cut answers (or sometimes fair answers) for enforceable situations (such as for example the Covid-19 pandemic) in which parties face disproportionate difficulties or an impossibility to perform their contractual obligations. In this respect, the ICC France Working Group on amiable composition observed that arbitrators with the power of deciding ex aequo et bono may inter alia accept a difficulty in performance as a force majeure even if it does not fulfil the required conditions. ${ }^{43}$

(ii) Statute of limitation:

As explained further in this article, arbitrators are not generally bound to mandatory provisions of the national law when deciding a case ex aequo et bono. How should a statute of limitations (which constitutes mandatory law in the majority of legal systems) be treated by the arbitral tribunals in ex aequo et bono arbitrations? Should it be applied at all, and if applied, should it be measured with standard rules of national law, or usages, or different solutions in comparable laws, to arrive at the most just result?

In this respect, BAT jurisprudence identified "two prerequisites" to consider a claim time barred/estopped, when discussing a claim stemming back to 2008: (i) "a substantial period of time has elapsed since the concerned claim fell due and [(ii)] the debtor has reasonable grounds to rely on the assumption that the creditor will not exercise his right in the future. The longer the period of time which has elapsed is, the easier it should (principally) be for the debtor to show that he justifiably relied on the creditor's waiver of his claims" ${ }^{4}$ This was the case for example when the creditor has failed to exercise its right for three, ${ }^{45}$ five ${ }^{46}$ or ten ${ }^{47}$ years.

(iii) Mitigation:

BAT case law has established a general duty to take reasonable steps to mitigate the consequences of the breach ${ }^{48}$ including in cases where the contract ex-

43 Edouard Bertrand, “Amiable Composition: Report of the ICC France Working Group”, International Business Law Journal, Vol. 6, 2005, 753, 762-763; N. Teramura, op. cit., 74.

44 BAT 1262/18, para. 42 to 44 (available at: https://bit.ly/2KDuDLC, 10.04.2020.).

45 BAT 0581; BAT 0879.

46 BAT 0777.

47 BAT $1262 / 18$, para. 45.

48 BAT 0824/16, para. 89 (available at: https://bit.ly/2Ja0y37, 10.042020.), BAT 1124/17, para. 46 (available at: https://bit.ly/2WVqmoE, 10.04.2020.). 
pressly excludes such a duty on the basis that it can lead to allegedly disproportionate results. ${ }^{49}$

(iv) Limitation and exclusion of liability:

Exclusion clauses are generally upheld in accordance with the principle of pacta sunt servanda and unless they are considered abusive..$^{50}$ Their validity basically depends on the circumstances of the case, and most frequently on whether those clauses were negotiated with, and accepted by, an informed party. ${ }^{51}$

(v) Penalties:

It would be hard to argue that the arbitral tribunal in ex aequo et bono arbitration would not have the right to, for instance, reduce the excessive contractual penalty clause, when this particular authority was even given to the court by the Serbian Law on Obligations if the court finds that the penalty is unproportionally high given the value and importance of the obligation. ${ }^{52}$ In this respect, BAT case law indicates that "contractual clauses which apply in the context of a breach, or termination for cause, such as penalties, or liquidated damages (this is not a closed list), are subject to careful scrutiny when ruling ex aequo et bono. In particular, such a clause which imposes a detriment on the contract-breaker out of all proportion to any legitimate interest of the innocent party, may be refused enforcement, or moderated in its application". ${ }^{53}$ In that particular case, having in mind the above-stated when deciding, the sole arbitrator found that the amount of a contractual penalty of $9 \%$ of the awarded claim was proportionate to the wrong which such a clause sought to address. ${ }^{54}$

(vi) Interest:

BAT arbitrators have awarded interest even in cases where it was not provided for in the contract, ${ }^{55}$ in cases where the basketball club has failed to fulfil its contractual obligation towards a player and their manager alleging that the player

49 BAT 1124/17, para. 46 to 50 (available at: https://bit.ly/2WVqmoE, 10.04.2020.).

50 BAT 1124/17, para. 49 (available at: https://bit.ly/2WVqmoE, 10.04.2020.).

51 BAT 1033/17, para. 111 to 113 (available at: https://bit.ly/2WZUEGB, 10.04.2020.).

${ }^{52}$ Law on Obligations, Official Gazette SFRJ, 29/78, 39/85, 45/89 - decisions of CSY and 57/89, Official Gazette SRJ, No. 31/93 and Official Gazette SCG, No. 1/2003, Art. 274.

53 BAT 0756/15, para. 62 (available at: https://bit.ly/2UoCZMd, 10.04.2020.).

54 Ibid., para. 85.

55 BAT 1115/17, para. 60 (available at: https://bit.ly/2RDr7BA, 10.04.2020.); BAT 1087/17, para. 53 (available at: https://bit.ly/2X2rBXP, 10.04.2020.); BAT 0949/16, para. 155 to 157 (available at: https://bit.ly/2WZ3xQN, 10.04.2020.), BAT 0392/13, para. 75 to 77 (available at: https://bit. ly/2IJz8Sv, 10.04.2020.). 
only appeared in one official game, suffered an injury and remained off the court for the rest of the season. This is a clear exception to the principle of pacta sunt servanda $a^{56}$ which is justified by the equitable consideration that "payment of interest is a customary and necessary compensation for late payment". ${ }^{57}$ Interest has not been awarded, however, in cases where both interest and penalties could amount to a "double compensation". 58

\section{Limits to the arbitrator's assessment}

The most frequently raised objection to ex aequo et bono is lack of predictability. Be it a high-level scrutiny of an arbitral institution or public policy of a country, it nonetheless appears that, in truth, certain safeguards exist to the benefit of consistency and predictability.

Jurisprudential limitations. - BAT case law suggests that the application of ex aequo et bono does not necessarily sacrifice the predictability of a given outcome. Article 16 (1) of the BAT Rules states that: "[b]efore signing the award the Arbitrator shall transmit a draft to the BAT President who may make suggestions as to the form of the award and, without affecting the Arbitrator's liberty of decision, may also draw his/her attention to points of substance. In the interest of the development of consistent BAT case law, the BAT President may consult with other BAT Arbitrators, or permit BAT Arbitrators to consult amongst themselves, on issues of principle raised by a pending case". Moreover, the BAT organizes periodical meetings for its arbitrators in which case law is discussed collectively. ${ }^{59}$

This consistent decision-making process not only disproves the prejudice that ex aequo et bono is unpredictable, but further shows that the application of ex aequo et bono can in fact lead to the creation of tailormade sets of global standards in a specific industry.

Statutory limitations. - It is undisputed that an award rendered when applying ex aequo et bono must be rendered in accordance with provisions pertaining to public policy. ${ }^{60}$ Public policy can be defined as a set of rules and principles that

56 BAT 0392/13, para. 75 to 77 (available at: https://bit.ly/2IJz8Sv, 10.04.2020.).

57 BAT 1115/17, para. 60 (available at: https://bit.ly/2RDr7BA, 10.04.2020.).

58 BAT 1115/17, para. 59 (available at: https://bit.ly/2RDr7BA, 10.04.2020.); BAT 1028/17, para. 134 (available at: https://bit.ly/2LfUrg5, 10.04.2020.); BAT 1048/17, para. 92 (available at: https://bit.ly/2RyX7GU, 10.04.2020.).

59 E. Hasler, op. cit., 105.

${ }^{60}$ N. Teramura, op. cit., 79; T. Zuberbühler, K. Muller, et al., op. cit., 299. 
reflect the fundamental and basic public and social values of a certain country. ${ }^{61}$ this implies that any award, including an award issued ex aequo et bono, must be in line with these provisions and principles.

The UNCITRAL Model Law (as well as Serbian Law on Arbitration) explicitly prescribes this as a reason for setting aside ${ }^{62}$ or for refusing to recognize $e^{63}$ an arbitral award. This is further corroborated by the Serbian Private International Law ("PIL") which prescribes that the law of a foreign country (or in this case $e x$ aequo et bono) shall not be applied if it is contrary to the public policy of the Republic of Serbia. ${ }^{64}$

Additionally, Serbian PIL further prescribes that if the parties' intent when choosing the applicable law is to avoid the application of the laws of Serbia, the chosen law shall not be applied. ${ }^{65}$ This provision raises the question whether $e x$ aequo et bono (as the parties' applicable choice of principles for adjudication) falls under this restriction - can an award be refused recognition or annulled if the parties chose ex aequo et bono for the purpose of avoiding the application of domestic (Serbian) law? Jurisprudence is of the opinion that the principle of fraus legis entails three preconditions - intent to avoid the application of a certain law, intent to apply a different law, and the creation of an artificial "connection point" in order to avoid the application of a certain law. Notably, there is no need to have any "connection point" in order to apply ex aequo et bono, which is why the choice of ex aequo et bono as the applicable principle cannot be automatically considered as fraus legis. The result might be different, if the only, or main, reason to apply ex aequo et bono is to avoid the application of Serbian public policy provisions.

Scholars and practitioners alike make a clear distinction between mandatory norms and public policy. Serbian courts have heeded this distinction, stating

61 Judgment of 8 December 2003, XXIX Y.B. Comm. Arb. 834 (Swiss Federal Tribunal) (2004), cited in Chapter 26: Recognition and Enforcement of International Arbitral Awards in G. Born, op. cit., 3684 .

62 UNCITRAL Model Law on International Commercial Arbitration (1985, with amendments as adopted in 2006), Article 34, Para. 2; Law on Arbitration, Official Gazette RS, No. 46/2006, Article 58, Para. 2.

63 UNCITRAL Model law on International Commercial Arbitration (1985, with amendments as adopted in 2006), Article 36, Para. 1; Law on Arbitration, Official Gazette RS, No. 46/2006, Article 66, Para. 2.

64 Serbian Private International Law, Official Gazette SFRY, No. 43/82 and 72/82, Official Gazette SRY, No. 46/96 and Official Gazette RS, No. 46/2006, Art. 4.

65 Serbian Private International Law, Official Gazette SFRY, No. 43/82 and 72/82, Official Gazette SRY, No. 46/96 and Official Gazette RS, No. 46/2006, Art. 5. 
that not every violation of a mandatory norm represents a violation of public poli$c y .{ }^{66}$ In this light, it can be considered that once the parties empower the arbitral tribunal to act in accordance with ex aequo et bono, they essentially grant the arbitral tribunal with the power to mitigate, or even disregards, the effects of mandatory norms of the national law. ${ }^{67}$

Just as arbitral tribunals do not have the obligation to apply mandatory norms of local substantive law ${ }^{68}$ other than the law agreed between the parties, the same applies when ex aequo et bono is the underlying principle. A very simple example is the case of statutes of limitations, which in most countries are considered as mandatory norms; arbitral tribunals should apply the statute of limitations rules of the chosen substantive law and not those provided in the national law of the seat of arbitration or of the enforcement of the award. The same solution is accepted in Serbian PIL. ${ }^{69}$ Mutatis mutandis, arbitral tribunals should not be bound by mandatory norms of national law also in the case of ex aequo et bono.

Any other solution would run afoul of (i) party autonomy and (ii) the very notion of ex aequo et bono. If the parties explicitly vested the arbitral tribunal with the power to decide ex aequo et bono, with the purpose of opting out of legislation they find unsuitable for their particular business relation or dispute, but find themselves subject to the mandatory norms of said legislation, this would deny the parties their autonomy to choose ex aequo et bono instead of an "applicable law". Secondly, the purpose of deciding ex aequo et bono would be defeated. If the purpose is for arbitrators to decide upon justice and equity, essentially compelling those same arbitrators to decide in accordance with the mandatory norms effectively negates the freedom of arbitrators and the express indication of ex aequo et bono. As such, it appears sensible to conclude that arbitrators are not obliged to act in accordance with the mandatory norms, nor should the awards rendered be required to be in accordance with mandatory norms.

The situation is somewhat different in relation to another concept of private international law that should be taken into consideration when contemplat-

${ }^{66}$ Judgement of the Serbian Commercial Court of Appeals No. Pž. 2765/2013 dated 23 January 2014 .

67 T. Zuberbühler, K. Muller, et al., op. cit., 299.

68 With the potential exception of mandatory norms of direct application, as described in the text bellow.

69 Serbian Private International Law, Official Gazette SFRY, No. 43/82 and 72/82, Official Gazette SRY, No. 46/96 and Official Gazette RS, No. 46/2006, Art. 8: "Law applicable to the substance of the matter or legal action is applicable for the statute of limitation". 
ing the issue of ex aequo et bono, namely the application of so-called overriding mandatory rules..$^{70}$ For the sake of clarity, there is a difference between mandatory norms as such (which is a broader range of norms within the applicable law that cannot be changed by will of the parties) and overriding mandatory rules (a narrower range of norms within mandatory norms, which are applied directly irrespective of the law otherwise applicable, i.e. norms of direct application). These rules do not completely override the applicable or chosen law; they only do so to the extent the chosen law is contrary to its "demands". ${ }^{71}$ These rules mostly deal with commercial, economic and financial rules of one country, such as tax and investment matters. Arguably, arbitrators should also observe the overriding mandatory rules when deciding, as these norms are much closer to public policy and in many instances can equate to public policy norms, (although this is not always the case; some of these norms are obviously not public policy).

Considering different reasons for setting aside and for refusing to recognize or enforce found in the most frequently used arbitration rules, it is clear that none of the grounds can be triggered merely because the arbitration proceedings were conducted ex aequo et bono. For instance, each reason for invalidity of the arbitration agreement provided in the Serbian Law on Arbitration ${ }^{72}$ should be assessed irrespective of whether it is an ex aequo et bono or ex lege arbitration. The same goes for all other reasons which may render an award unenforceable or set aside under the Serbian Law on Arbitration.

\section{PROS AND CONS}

Theory and practice concur that efficiency and procedural economy is the main advantage of ax aequo et bono proceedings.

In the phase of the case management conference and preparation of terms of reference, the determination of the law applicable to the merits becomes a lengthy one due to the invocation of conflict of law rules. Furthermore, much of the exchange of arguments between the parties relies on different interpretations of national law provisions. Very often parties appoint legal experts to support their positions regarding the interpretation and application of national law. Ex aequo et bono proceedings in turn dispense with such questions. This is not to suggest that

70 Mandatory rules of law; Norms of direct application; Lois de police; Norme neposredne primene.

71 Jelena Stojšić Dabetić, “Overriding mandatory rules in international private law”, Pravo teorija i praksa, No. 4-6, Novi Sad, 2018, 49.

72 Law on Arbitration, Official Gazette RS, No. 46/2006, Art. 10. 
the parties do not argue and present different interpretations from the perspective of national laws in support of their respective positions; still, extensive discussions and argumentation on such issues becomes somewhat superfluous. Arbitral tribunals are absolved of the obligation to determine the content of foreign national laws, and to instruct the parties to provide different explanations and interpretations of national laws. By that fact alone, written submissions become shorter, oral presentations and arguments become more efficient, and the duration of the case shortens. Effectively, this significantly reduces the costs of the arbitration for both parties.

Finally, the ex aequo et bono "discretion" of arbitrators may help improve the efficiency of arbitration proceedings. In recent years, arbitrators have tended to overcomplicate and prolong the procedings, due to the so-called "due process paranoia" - a perceived reluctance by arbitral tribunals to act decisively in certain situations for fear of the award being challenged on the basis of a party not having had the chance to fully present its case. ${ }^{73}$ Arbitrators are therefore forced to either decide the case in accordance with the legal arguments provided by the parties or give each party the opportunity to present their respective case on legal issues (not addressed by the parties) that the arbitrators deem relevant to the outcome of the case. This exercise is not only time-consuming, but may further induce an effort by the losing party to have the award annulled on the basis of the fact that the arbitrators' legal questions would be tantamount to unequal treatment, by somehow improving the case of the opposing party. Thus, reducing the legal issues at stake enhances the arbitrators' authority to efficiently adjudicate the dispute. ${ }^{74}$

Another time-consuming and costly exercise is the appointment of one or more experts during the course of the arbitration. Arbitral tribunals tend to rely extensively on guidance given by experts in different fields. Best practices and industry standards (about which experts are best to testify), among others, become particularly useful and important for the arbitral tribunal when adjudicating the most just and fair solutions. Experts are not usually able to act as arbitrators given their lack of knowledge of the law applicable to the case. The application of ex aequo et bono increases the possibility of appointing an expert as an arbitrator in order to adjudicate the dispute not in accordance with the applicable law but in

73 Queen Marry and White \& Case 2015 International Arbitration Survey: Improvements and Innovations in International Arbitration, 2.

${ }^{74}$ N. Teramura, "Ex Aequo et Bono: An Overlooked and Undervalued Opportunity for International Commercial Arbitration”, Kluwer Arbitration Blog, 2018. 
accordance with what is fair and reasonable in a certain specific industry. Isn't this what users expect from arbitration?

As explained above, in ex aequo et bono proceedings, the focus of arbitrators, counsel and parties is taken off from interpretation and application of nationals laws to give primary focus to the facts of the case and to interpretation and application of contract concluded between the parties. Scholars observe that the outcome of the case is less and less dependent on legal issues than on the complexity of the contract, how it was concluded and implemented. ${ }^{75}$ It therefore seems that ex aequo et bono permits the actors of the arbitration proceedings to focus exclusively on what matters the most.

Lastly, the application of a specific national law (i) can be unreasonably costly for parties who cannot afford to pay the legal fees of lawyers based in very expensive jurisdictions; (ii) limits the parties' right to choose the counsel of their choice; (iii) has a negative impact on arbitrator diversity. Ex aequo et bono permits the hiring of counsel and arbitrators who are familiar with the parties' culture and needs.

\section{CONCLUSIONS}

Ex Aequo et bono is not a particularly popular concept in international arbitration. Due to concerns of uncertainty, unpredictability and presumably excessive discretion by arbitrators, attorneys and in-house counsel have tended to avoid conferring upon tribunals the authority to decide ex aequo et bono. The present article has attempted to highlight that any such concerns are not ex aequo et bono-specific, but are rather inherent to general and universal concerns in international arbitration. They are only amplified by the fact that ex aequo et bono is an unknown ground for practitioners and users. As such, despite concerns that $e x$ aequo et bono is unpredictable and potentially too arbitrary and subjective, a sophisticated application of ex aequo et bono could lead to the simplification of the dispute resolution system while ensuring a fair and predictable outcome.

As the article has set out in detail, efficiency and cost-effectiveness, focus on facts and interpretation of contracts, as well as wider freedom of selection of arbitrators and legal counsel are among the most important advantages ex aequo et bono offers vis-à-vis an applicable set of norms of a specific national legal order. Furthermore, ex aequo et bono opens the door for users to appoint industry experts as arbitrators in an attempt to obtain the most efficient and industry-adjusted resolution of their case.

75 B. Berger, F. Kellerhals, op. cit., para. 1445. 
Interestingly enough, this may be the moment in time when ex aequo et bono gains traction in light of the crisis generated by the COVID-19 pandemic, which more than ever calls for flexibility in resolving contentious situations. Contractual parties are currently facing difficulties in performing their obligations due to the pandemic, often relying upon force majeure or hardship clauses. Parties, as well as the tribunals, may seek reliance on the principles of ex aequo et bono in cases where the formal conditions for force majeure or hardship clauses to be triggered under national laws are not fulfilled, and where it would still be unfair not to acknowledge the difficulties COVID-19 poses to contractual performance. It remains to be seen whether the pandemic will at least increase the application of ex aequo et bono as a supplemental principle to substantive national laws.

MILAN LAZIĆ

Stariji partner, advokat, Advokatska kancelarija

Karanović \& Partners, Beograd

GIULIO PALERMO

Partner, advokat, Advokatska kancelarija Archipel

Ženeva

SRĐAN DRAGIĆEVIĆ

Pravnik, Advokatska kancelarija Karanović \& Partners

Beograd

\title{
EX AEQUO ET BONO U MEĐUNARODNOJ ARBITRAŽI
}

\author{
Rezime
}

U radu se analizira institut ex aequo et bono u arbitraži, uz polazište da on ne podrazumeva nijedan dodatni rizik koji nije svojstven rešavanju sporova generalno. $\mathrm{S}$ druge strane, ex aequo et bono poseduje atribute koji bi mogli da unaprede i poboljšaju postupak rešavanja sporova, kao što su veći akcenat na činjenicama, princip tzv. "korektivne pravde" i pravična rešenja koja nisu sputana i ograničena strogim zakonskim odredbama. Iako je u određenim oblastima ili predmetima primena ovog instituta možda lakša i prirodnija (kao što je sportska arbitraža), autori smatraju da bi institut ex aequo et bono trebalo primeniti u mnogo širem spektru slučajeva jer bi primena ovog instituta mogla da pojednostavi, ubrza i uopšte unapredi arbitražni postupak ali i da jasnije istakne razliku između arbitraže i previše formalnog pristupa državnih sudova. Na kraju, izbor ex aequo et bono je izričito predviđen i dozvoljen u brojnim arbitražnim pravilima i zakonima, čineći odluke donete uz ex aequo et bono izvršivim u velikom broju jurisdikcija.

Ključne reči: fleksibilnost, priznanje, izvršenje, poništaj, sportska arbitraža 
Bibliography

Berger B., Kellerhals F., International and Domestic Arbitration in Switzerland, Bern, 2015.

Bertrand E., "Amiable Composition: Report of the ICC France Working Group", International Business Law Journal, No. 6, 2005.

Born G., International Commercial Arbitration, Kluwer Law International, 2014.

Christie R.H., "Amiable composition in French and English law" Arbitration, Vol. 58, No. 4, 1992.

Greenberg S., Kee C., Weeramantry J., International Commercial Arbitration: An Asia-Pacific Perspective, New York, Cambridge University Press, 2011.

Hasler E., "The Basketball Arbitral Tribunal - An Overview of Its Process and Decisions", Yearbook of International Sports Arbitration 2015, The Hague, 2016.

Hasler E., "Back to the Future: The First CAS Arbitrators on CAS's First Award (TAS 86/1, HC X c. LSHG) and Its Evolution Since Then", Yearbook of International Sports Arbitration 2016, The Hague, 2018.

Kaufmann-Kohler G., Rigozzi A., Arbitrage international: droit et pratique à la lumière de la LDIP, Bern, Weblaw, 2010.

Kroll S., "Contractual Gap-Filling by Arbitration Tribunals", International Arbitration Law Review, Vol. 2, No. 1, 1999.

Queen Marry and White \& Case 2015 International Arbitration Survey: Improvements and Innovations in International Arbitration.

Stojšić Dabetić J., “Overriding mandatory rules in international private law”, Pravo - teorija i praksa, No. 4-6, Novi Sad, 2018.

Tanaka Y., "Reflections on maritime delimitation in the Cameroon/Nigeria case", International \& Comparative Law Quarterly, Vol. 53, 2004.

Teramura N., "Ex Aequo et Bono: An Overlooked and Undervalued Opportunity for International Commercial Arbitration", Kluwer Arbitration Blog, 2018.

Teramura N., “The Strengths and Weaknesses of Arguments Pertaining to Ex Aequo Et Bono", Asian International Arbitration Journal, Kluwer Law International, Vol. 15, 2019.

Waincymer J., Procedure and Evidence in International Arbitration, Kluwer Law International, 2012.

Zuberbühler T., Muller K., et al., Swiss Rules of International Arbitration: Commentary, Kluwer Law International, 2005.

Article history

Received: 16.04.2020.

Accepted: 27.04.2020.

ORIGINAL SCIENTIFIC PAPER 